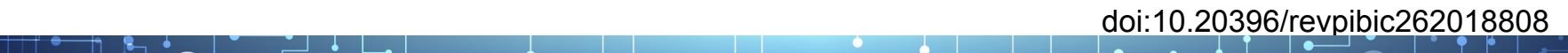

\section{Congresso de Iniciação Científica Unicamp}

Fabricação de pontas de tungstênio para STM.

\section{SANTANA L. A. ${ }^{*}$, Zagonel L. F., Auad Y. M.}

\section{Resumo}

O trabalho se baseou principalmente em encontrar um sistema de fabricação de pontas para STM com uma eletrônica mais acessível. Foi utilizada a plataforma de prototipagem eletrônica Arduíno e obteve-se imagens com resolução atômica no microscópio.

\section{Palavras-chave:}

STM, Arduíno, tungstênio.

\section{Introdução}

Um STM, microscópio de varredura de tunelamento, é um equipamento que possibilita obter informações da superfície de um material com resolução atômica. Dentre as partes desse equipamento está uma ponta de tungstênio mostrada na Figura 2. Quanto mais aguda for a ponta e quanto menor for seu raio, melhor a resolução do equipamento.

O processo de fabricação dessa ponta já foi bem explorado. Mas os circuitos apresentados na literatura são complicados. O objetivo do trabalho é encontrar um circuito mais simples capaz de atender às necessidades do processo de fabricação obtendo pontas com raio menor que $1 \mu \mathrm{m}$.

\section{Resultados e Discussão}

A fabricação das pontas é feita por corrosão eletroquímica em um fio de tungstênio. Na Figura 1, o fio é imerso em uma solução de hidróxido de sódio e é aplicada uma diferença de potencial entre o frio e um eletrodo de aço inox também imerso na solução. $O$ importante é que o raio da ponta está relacionado a rapidez de controle do circuito eletrônico'.

A plataforma Arduíno é um dispositivo que possibilita esse controle eletrônico na fabricação e ao mesmo tempo apresenta facilidade em sua operação.

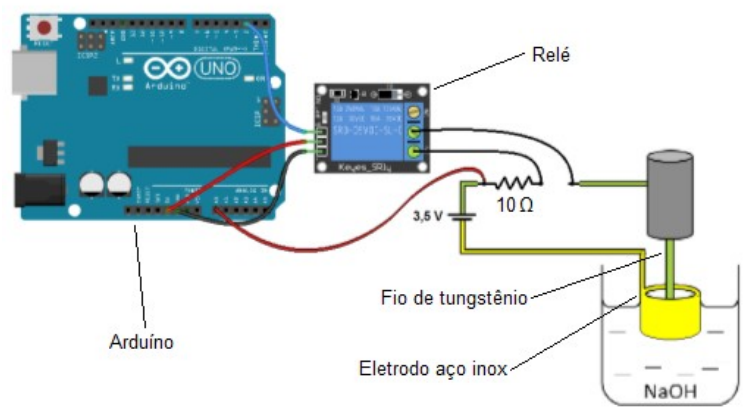

Figura 1. Sistema de fabricação das pontas.

Assim, o Arduíno foi testado na fabricação de pontas de tungstênio utilizando um rele mecânico. Pontas de tungstênio pontas de tungstênio, como a da Figura 2, foram fabricadas e testadas no microscópio. Esse teste resultou em imagens de superfície com resolução atômica, Figura 3.

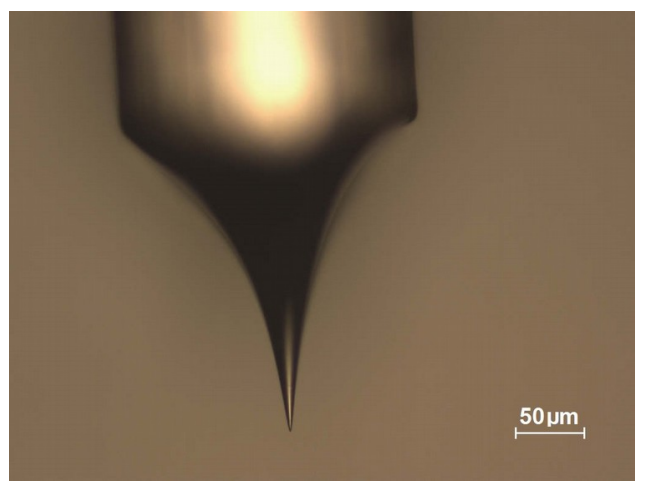

Figura 2. Ponta em microscópio ótico.

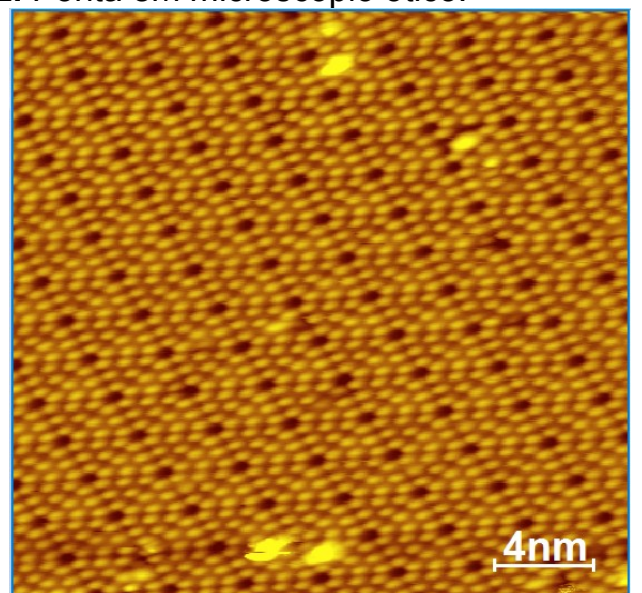

Figura 3. Imagem de Si7x7 no microscópio.

\section{Conclusão}

Portando, o Arduíno pode ser utilizado como um circuito eletrônico alternativo para a produção de pontas de tungstênio para STM com medidas de resolução atômica. Além disso esse dispositivo tem software de programação livre é muito versátil.

Ainda estão sendo estudados outros circuitos para aumentar a rapidez de controle dos sinais, como transistores TBJ e JFET. Para cada tipo de componente de controle, será feita estudando o tempo de resposta e o raio da ponta de tungstênio.

\section{Agradecimentos}

Agradecemos ao SAE/UNICAMP.

${ }^{1}$ CHEN, C. Julian. Introduction to scanning tunneling microscopy. Oxford University Press, 2008, p. 315. 